\title{
Glomerular vascular cell adhesion molecule-1 expression in renal vasculitis
}

\author{
A A Pall, A J Howie, D Adu, G M Richards, C D Inward, D V Milford, \\ N T Richards, J Michael, C M Taylor
}

\begin{abstract}
Aims-To study the expression of cell adhesion molecules in the renal biopsy specimens of patients with systemic vasculitis and Henoch-Schönlein purpura (HSP); to correlate this with the severity of glomerular inflammation.

Methods-Renal biopsy specimens obtained from eight patients with untreated systemic vasculitis (four with Wegener's granulomatosis and four with microscopic polyarteritis), eight with HSP and nine controls (four with normal histopathology and five with thin glomerular basement membrane disease) were stained using the alkaline phosphatase anti-alkaline phosphatase method with monoclonal antibodies directed against intercellular adhesion molecule-1 (ICAM-1), vascular cell adhesion molecule-1 (VCAM-1) and E-selectin.
\end{abstract}

Results-Biopsy specimens of normal kidneys expressed ICAM-1 in glomerular endocapillary cells, Bowman's capsule epithelium, interstitial cells and interstitial vascular endothelium, and VCAM1 in Bowman's capsule epithelium, proximal tubular epithelium and interstitial vascular endothelium. No staining with antibody directed against E-selectin was seen in any of the biopsy specimens. $\mathrm{Bi}$ opsy specimens of patients with a vasculitic glomerulonephritis (segmental necrotising glomerulonephritis) expressed VCAM-1 in glomerular endocapillary cells (four of eight patients with systemic vasculitis; two of eight patients with HSP). In patients with a systemic vasculitis glomerular VCAM-1 expression was associated with a more severe renal lesion $(44,50,60$, and $65 \%$ of glomeruli involved) than in those not showing glomerular VCAM- 1 expression $(3,3,11$, and $39 \%$ of glomeruli involved).

Conclusion-Expression of VCAM-1 by glomerular endocapillary cells in renal biopsy specimens raises the possibility that recruitment of VLA-4 bearing leucocytes may contribute to glomerular injury in Wegener's granulomatosis and microscopic polyarteritis.

(f Clin Pathol 1996;49:238-242)

Keywords: renal vasculitis, VCAM-1, ICAM-1, Eselectin.

Cell adhesion molecules (CAMs) regulate the interaction between leucocytes and renal par- enchymal cells and are likely to play a major role in renal inflammation. CAMs expressed by the human kidney include the glycoproteins, intercellular adhesion molecule-1 (ICAM-1, CD54) and vascular cell adhesion molecule-1 (VCAM-1), ${ }^{1}$ which belong to the immunoglobulin supergene family. On endothelium their expression is regulated by interleukin-1 (IL-1), tumour necrosis factor (TNF) and $\gamma$ interferon $(\gamma \mathrm{IFN})$ in the case of ICAM $-1^{2}$ and IL-1, TNF and IL-4 in the case of VCAM-1. ${ }^{34}$ ICAM-1 is widely distributed and expressed on a variety of cells, including lymphocytes, endothelial cells and epithelial cells, and binds to the $\beta 2$-integrins lymphocyte function associated (LFA-1) antigen (CD11a/CD18) and Mac-1 (CD11b/CD18) on lymphocytes, neutrophils and monocytes. ${ }^{5-7}$ VCAM-1 has a more restricted distribution, being found on endothelial cells, follicular dendritic cells, cultured neural cells, glomerular epithelial and mesangial cells, and vascular smooth muscle cells. ${ }^{8}$ VCAM- 1 binds to the $\beta 1$-integrin VLA-4 (CD49d/CD29) on lymphocytes, eosinophils, monocytes, and basophils. ${ }^{9}$ On in vitro culture of human kidney with TNF, glomerular endothelial cells express E-selectin, ${ }^{10}$ which recognises and binds to carbohydrate sequences on neutrophils and to a subpopulation of memory $\mathrm{T}$ lymphocytes that express a carbohydrate known as cutaneous lymphocyte associated antigen. $^{11}$

The specific interaction of subsets of leucocytes with endothelium expressing VCAM1, ICAM-1 and E-selectin is important in the adhesion of leucocytes to the endothelium and their transmigration across the endothelium to sites of inflammation. ${ }^{12-14}$ In addition, the interaction between lymphocytes and ICAM1 and VCAM-1 provides an important co-stimulatory signal for $\mathrm{T}$ lymphocyte activation. ${ }^{1516}$ Normal human glomerular endothelium expresses ICAM-1, and Bowman's capsule cells express ICAM-1 and VCAM-1. ${ }^{1017-19}$ During allograft rejection ${ }^{20}$ and in patients with glomerulonephritis, ${ }^{17} 18$ interstitial nephritis and vasculitis, ${ }^{19}$ ICAM1 and VCAM-1 are also expressed by renal proximal tubular epithelial (PTE) cells.

The mechanism of the vascular, extracapillary and interstitial injury and inflammation in segmental necrotising glomerulonephritis is not known. The aim of our study was to examine the expression of ICAM-1, VCAM-1 and E-selectin in kidney biopsy specimens of patients with renal vasculitis and to correlate this with lesion severity. 
Table 1 Distribution of ICAM-1 expression: numbers of positively stained sections

\begin{tabular}{llllll}
\hline Biopsy specimen & GEC & $\begin{array}{l}\text { Bowman's } \\
\text { capsule } \\
\text { epithelium }\end{array}$ & $\begin{array}{l}\text { Proximal } \\
\text { tubular } \\
\text { epithelial cells }\end{array}$ & $\begin{array}{l}\text { Interstitial } \\
\text { cells }\end{array}$ & $\begin{array}{l}\text { Interstitial } \\
\text { vascular } \\
\text { endothelium }\end{array}$ \\
\hline Normal $(\mathrm{n}=9)$ & 9 & 9 & 1 & 9 & 6 \\
WG/MPA $(\mathrm{n}=8)$ & 8 & 8 & 5 & 8 & 5 \\
HSP $(\mathrm{n}=8)$ & 8 & 8 & 1 & 8 & 4 \\
\hline
\end{tabular}

GEC = glomerular endocapillary cells; WG = Wegener's granulomatosis

Table 2 Distribution of VCAM-1 expression: numbers of positively stained sections

\begin{tabular}{llllll}
\hline Biopsy specimen & GEC & $\begin{array}{l}\text { Bowman's } \\
\text { capsule } \\
\text { epithelium }\end{array}$ & $\begin{array}{l}\text { Proximal } \\
\text { tubular } \\
\text { epithelial cells }\end{array}$ & $\begin{array}{l}\text { Interstitial } \\
\text { cells }\end{array}$ & $\begin{array}{l}\text { Interstitial } \\
\text { vascular } \\
\text { endothelium }\end{array}$ \\
\hline Normal $(\mathrm{n}=9)$ & 0 & 9 & 7 & 1 & 5 \\
WG/MPA $(\mathrm{n}=8)$ & 4 & 8 & 8 & 2 & 4 \\
HSP $(\mathrm{n}=8)$ & 2 & 8 & 7 & 2 & 1 \\
\hline
\end{tabular}

$\mathrm{GEC}=$ glomerular endocapillary cells; WG $=$ Wegener's granulomatosis.

\begin{abstract}
Methods
Diagnostic renal core biopsy specimens were obtained from eight patients with a primary systemic necrotising vasculitis (four with Wegener's granulomatosis and four with microscopic polyarteritis (MPA)) and eight with Henoch-Schönlein purpura (HSP) using the standard percutaneous Trucut needle technique. All patients had active disease and underwent biopsy prior to any immunosuppressive treatment. The diagnosis of systemic vasculitis was made using established clinical and histological criteria ${ }^{21}$ and of HSP by conventional criteria. All but one of the patients with systemic vasculitis were positive for antineutrophil cytoplasmic antibody, with a mean age of 52 years (range 26-70 years) and mean serum creatinine concentration of $229 \mu \mathrm{mol} / 1$ (range $69-489 \mu \mathrm{mol} / \mathrm{l}$ ). In the patients with HSP the mean age was 32 years (range two to 81 years) and mean serum creatinine concentration was $104 \mu \mathrm{mol} / 1$ $(37-196 \mu \mathrm{mol} / 1)$. The control group $(n=9)$ comprised four patients with microscopic haematuria, but in whom subsequent complete histological examination including electron microscopy failed to reveal any abnormalities,
\end{abstract}

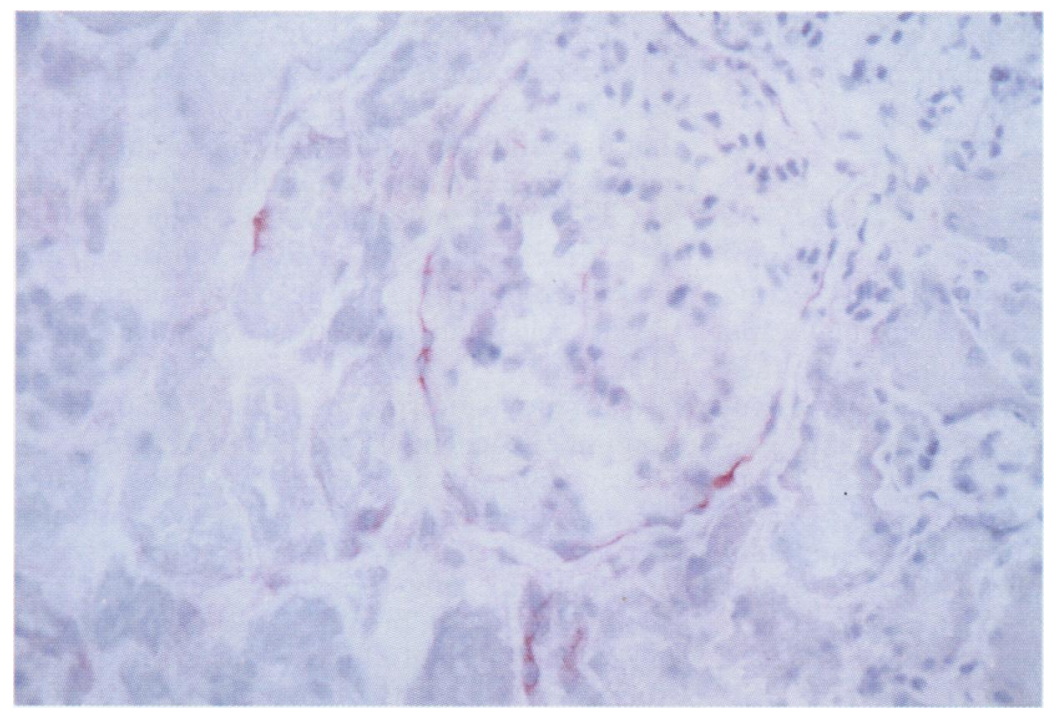

Figure 1 Normal renal biopsy specimen stained with monoclonal antibody directed against VCAM-1. Reactivity seen in Bowman's capsule epithelium, proximal tubular epithelium, interstitial vascular endothelium, and interstitial cells. $(A P A A P \times 200$.) and five patients with thin glomerular basement membrane disease. One core of each renal biopsy specimen was collected in formol saline, embedded in paraffin wax and stained routinely for histological examination. A separate core biopsy specimen was immediately embedded in OCT (Cryo-M-Bed (Bright, Huntingdon, UK)), snap frozen in liquid nitrogen and stored at $-70^{\circ} \mathrm{C}$ until studied.

\section{IMMUNOHISTOCHEMICAL STAINING FOR CAMS} Frozen tissue was studied immunohistochemically for CAM expression using the alkaline phosphatase antialkaline phosphatase (APAAP) technique. ${ }^{22}$ Briefly, frozen sections were cut at $6 \mu \mathrm{m}$, air dried on a slide and fixed with acetone for five minutes. Sequential incubations were performed as follows: (1) mouse monoclonal IgG1 antibodies directed against ICAM-1 ( $R$ and D Systems, Oxford, UK; clone BBIG-I1), VCAM-1 (R and D systems; clone BBIG-V1) or E-selectin (R and D systems; clone BBIG-E6), each diluted 1 in 10 in $0.05 \mathrm{M}$ Tris buffered saline (TBS) ( $\mathrm{pH} 7 \cdot 6$ ); (2) rabbit anti-mouse immunoglobulins (IgG) (Dako, High Wycombe, UK), diluted 1 in 25 in TBS; APAAP mouse monoclonal antibody to IgG1 $\kappa$ (Dako; clone AP7/6/7), diluted 1 in 50 in TBS. All incubations were performed in a moist box at room temperature for 30 minutes and slides were washed between incubations in an agitated TBS bath. The stain was developed with fast red substrate (naphthol AS-MX phosphate free acid, dimethyl $0.2 \mathrm{ml}, 0.1 \mathrm{M}$ Tris buffer ( $\mathrm{pH} 8 \cdot 2), 1 \mathrm{M}$ levamisole $(10 \mu \mathrm{l})$ and fast red TR salt $(10 \mathrm{mg})$ ) for 15 minutes at room temperature, then rinsed with TBS and distilled water, counterstained with Mayer's haemalum (Sigma, Poole, Dorset, UK), and mounted in Glycergel (Dako). As controls, each section was stained without monoclonal anti-CAM antibody. The stained sections were viewed under light microscopy by a pathologist who had no knowledge of the underlying diagnosis and who recorded the cellular distribution of the adhesion molecules.

\section{Results}

EXPRESSION OF ICAM-1 AND VCAM-1

Tables 1 and 2 summarise the distribution of ICAM-1 and VCAM-1 expression in the biopsy specimens. Biopsy specimens of normal kidneys expressed ICAM-1 in glomerular endocapillary cells, Bowman's capsule epithelium, interstitial cells and some endothelium of interlobular arteries in the interstitium. Biopsy specimens from patients with Wegener's granulomatosis and MPA also expressed ICAM-1 in proximal tubular epithelial cells in five of eight cases. There was no VCAM-1 expression on glomerular endocapillary cells in the normal kidney and its expression was restricted to Bowman's capsule epithelium, some proximal tubular epithelial cells and interstitial vascular endothelium (fig 1). Biopsy specimens from four of eight patients with idiopathic vasculitis and two of eight patients with HSP showed staining of glomerular endo- 


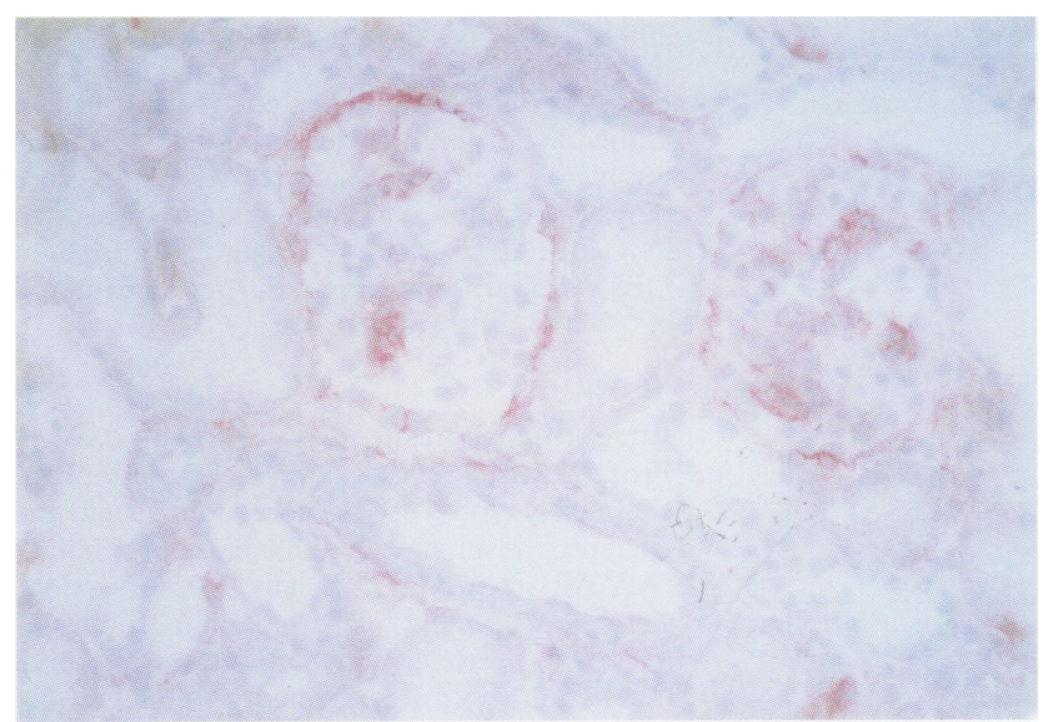

Figure 2 Vasculitic renal biopsy specimen stained with monoclonal antibody directed against VCAM-1. Reactivity as seen in the normal biopsy specimen with additional staining in glomerular endocapillary cells. $($ APAAP $\times 200$.)

capillary cells with VCAM-1 (fig 2). VCAM-1 was also found in Bowman's capsule epithelium, proximal tubular epithelial cells, interstitial vascular endothelium and also some interstitial cells. There was no staining for Eselectin in any of the tissues studied.

\section{SEVERITY OF RENAL VASCULITIS AND VCAM-1} EXPRESSION

The percentage of glomeruli with a segmental necrotising glomerulonephritis in biopsy specimens from patients with Wegener's granulomatosis ranged from 3 to $65 \%$ and in those with HSP from 6 to $54 \%$. In biopsy specimens from patients with Wegener's granulomatosis and MPA the expression of VCAM-1 by glomerular endocapillary cells was associated with a more severe renal lesion; 44, 50, 60, and $65 \%$ of glomeruli had vasculitic lesions compared with $3,3,11$, and $39 \%$ of glomeruli in the absence of VCAM-1 expression by glomerular endocapillary cells. In HSP there was no correlation between the proportion of glomeruli with a vasculitic lesion and expression of VCAM-1 by glomerular endocapillary cells (data not shown).

\section{Discussion}

CAMs play a critical role in the migration of leucocytes to sites of inflammation, in selecting the types of leucocytes that accumulate and in modifying leucocyte function. Thus, they provide a mechanism by which leucocytes accumulate in renal tissues, which leads to glomerular and interstitial inflammation. The renal histology in active Wegener's granulomatosis and MPA is of a focal segmental necrotising glomerulonephritis with or without extracapillary proliferation (crescent formation) and often an interstitial infiltrate of mononuclear cells. ${ }^{23-25}$ The kidney in HSP shows a focal segmental proliferative glomerulonephritis that in some cases is accompanied by a segmental necrotising glomerulonephritis, crescent formation and a glomerular infiltrate of macrophages. ${ }^{26}$ The glomerular lesions in Wegener's granulomatosis and MPA usually show few, if any, immune deposits (so called pauci-immune glomerulonephritis), ${ }^{27}$ whilst in HSP there is mesangial deposition of $\operatorname{IgA} .^{28}$ Studies of renal histology in patients with Wegener's granulomatosis and MPA have shown that cells within glomeruli and in crescents express TNF and IL-1. Double immunostaining identified these cells as infiltrating monocytes/macrophages. CD3 and IL-2R positive T cells were also identified in crescents, in the periglomerular area and in the interstitium ${ }^{29}$; neutrophils are also found within the glomeruli. ${ }^{30}$ IL-1 is produced by cultured human mesangial cells $^{3132}$ and is known to upregulate the expression of ICAM-1 and VCAM-1 on venous endothelium. ${ }^{33}$ The expression of VCAM-1 is also increased by IL-4 produced by T cells. ${ }^{34-35}$

The major observation in this study is that the glomerular endocapillary cells in half of the patients with active renal vasculitis and a quarter of the patients with HSP expressed VCAM-1. Expression of VCAM-1 was not seen in glomerular endocapillary cells in any of the normal biopsy specimens studied. Occasional staining of glomerular capillary walls with antibodies directed against VCAM-1 was seen in biopsy specimens of patients with HSP and Wegener's granulomatosis in the study by Bruijn and Dinklo. ${ }^{36}$ By contrast, no glomerular or peritubular capillary staining of VCAM-1 was seen in the biopsy specimens of seven patients with a vasculitis studied by Seron et al. ${ }^{19}$ In keeping with our observations, however, human glomerular endothelium has been shown to express VCAM-1 following in vitro incubation of kidney sections with TNF. ${ }^{10}$ In our study the expression of VCAM-1 in glomerular endocapillary cells in biopsy specimens of patients with Wegener's granulomatosis and MPA, but not with HSP, was associated with a more severe renal lesion, as assessed by the proportion of glomeruli affected by a segmental necrotising glomerulonephritis. VCAM-1 expression by glomerular endocapillary cells may be important in selectively recruiting monocytes/macrophages and $T$ lymphocytes that express VLA-4 (CD49d/CD29) and it is possible that this adhesion molecule is important in the genesis of this type of glomerular inflammation. As previously reported VCAM-1 expression in the normal kidney was restricted to Bowman's capsule epithelium, some proximal tubular epithelial cells and interstitial vascular endothelium. ${ }^{36}$

Our study confirms the findings of previous immunohistochemical studies of ICAM-1 expression in normal human kidneys. ${ }^{17} 18$ Thus, the normal kidney expresses ICAM-1 on glomerular endocapillary cells, interstitial vascular endothelium and Bowman's capsule epithelium, but not proximal tubular epithelial cells. The "normal" biopsy specimens in our study were obtained from patients with noninflammatory renal disease and were as close as one can get to normal renal tissue for ethical reasons. The glomerular endocapillary cells in 
the biopsy specimens of patients with Wegener's granulomatosis, MPA and HSP expressed ICAM-1; this expression did not differ qualitatively from that found in normal specimens. There was no expression of E-selectin in the glomerular endocapillary cells of either controls or patients. Glomerular endothelium does express E-selectin in vitro ${ }^{10}$ and we have reported a case of pyelonephritis in a patient with diabetes mellitus in which there was staining of glomerular endothelium for E-selectin using the same antibody as used in the present study. ${ }^{37}$

In the present study, as in the study of Seron et $a l,{ }^{19}$ proximal tubular epithelial cells in the biopsy specimens of patients with renal vasculitis expressed ICAM-1 and this was only rarely seen in normal specimens and in specimens of patients with HSP. Proximal tubular ICAM-1 expression is also seen in primary glomerulonephritides, lupus nephritis and renal allograft rejection. ${ }^{17-20}$ In addition to their role in the recruitment of leucocytes to the sites of inflammation, VCAM-1 and ICAM-1 can produce co-stimulatory signals that are essential for the activation of T lymphocytes. ${ }^{15} 16$ Cultured murine proximal tubular epithelial cells are capable of acting as accessory cells for the processing and presentation of antigen to $\mathrm{T}$ cell hybridomas ${ }^{38}$ and if human proximal tubular epithelial cells behave similarly, ${ }^{39}$ then that could provide a mechanism for the tubulointerstitial nephritis often seen in renal vasculitis. $^{27}$

Cultured human glomerular epithelial, proximal tubular epithelial and mesangial cells also express ICAM-1 and VCAM-1, ${ }^{40-45}$ and are able to bind specific ligand bearing peripheral blood mononuclear cells. Human glomerular epithelial cells constitutively express ICAM-1 and VCAM-1 with upregulation of VCAM-1 by IL-4, but not by TNF or IL-1. Unlike vascular endothelial cells, ICAM-1 expression on glomerular epithelial cells is not altered by TNF, $\gamma$ IFN or IL-1..$^{40}$ Cultured human proximal tubular epithelial and mesangial cells also constitutively express ICAM-1 and VCAM-1 and the levels of these CAMs are upregulated by TNF and IFN. ${ }^{41-45}$ There is as yet little information on the regulation of adhesion molecule expression and function of cultured human glomerular endothelial cells. Monoclonal antibodies directed against ICAM-1, VLA-4 and LFA-1 are effective in reducing the inflammatory lesions and proteinuria in animal models of anti-glomerular basement membrane nephritis. This indicates that CAMs play a critical role in the genesis of glomerular inflammation. ${ }^{46}$ In humans there has been some therapeutic success with monoclonal anti-ICAM-1 in renal allograft rejection. ${ }^{47}$ Increased understanding of the role of CAMs in the inflammation and injury seen in renal vasculitis may lead to more specific immunotherapy in these patients.

This study was supported by a grant from the Birmingham (QE) Kidney Research Fund. We are grateful to Mrs Judy Davies for secretarial help.
1 Wuthrich RP. Intercellular adhesion molecules and vascular cell adhesion molecule- 1 and the kidney. $\mathcal{F}$ Am Soc Nephrol 1992;3:1201-11.

2 Simmons D, Makgoba MW, Seed B. ICAM, an adhesion ligand of LFA-1, is homologous to the neural cell adhesion molecule NCAM. Nature 1988;331:624-7.

3 Polte T, Newman W, Venkat Gopal T. Full length vascular cell adhesion molecule 1 (VCAM-1). Nucleic Acids Res 1990;18:5901.

4 Osborn L, Hession C, Tissard R, Vassallo C, Luhowskyi S, Chi-Rosso G, et al. Direct expression cloning of vascular cell adhesion molecule-1, a cytokine-induced endothelial protein that binds to lymphocytes. Cell 1989;59:1203-11.

5 Marlin SD, Springer TA. Purified ICAM-1 is a ligand for lymphocyte function associated antigen (LFA-1). Cell for lymphocyte func

6 Dustin ML, Springer TA. Lymphocyte function-associated antigen-1 (LFA-1) interaction with intercellular adhesion molecule-1 (ICAM-1) is one of at least three mechanisms for lymphocyte adhesion to cultured endothelial cells. $f$ Cell Biol 1988;107:321-31.

7 Diamond MS, Staunton DE, Marlin SD, Springer TA. Binding of the integrin Mac-1 to the third immunoglobulin-like domain of ICAM-1 (CD54) and its munoglobulin-like domain of

8 Pober JS, Cotran RS. What can be learned from the expression of endothelial adhesion molecules in tissues? Lab Invest 1991;64:301-5.

9 Elices MJ, Osborn L, Takada Y, Crouse C, Luhowsky JS, Hemler ME, et al. VCAM-1 on activated endothelium interacts with the leucocyte integrin VLA-4 at a site distinct from the VLA-4/fibronectin binding site. Cell 1990;60: 577-84.

10 Briscoe DM, Cotran RS. Role of leucocyte-endothelial cell adhesion molecules in renal inflammation: In vitro and in vivo studies. Kidney Int 1993;44(Suppl 42):S27-34.

11 Phillips ML, Nudelman E, Gaeta FCA. ELAM-1 mediates cell adhesion by recognition of a carbohydrate ligand, sialyl-Le ${ }^{x}$. Science 1990;250:9557-60.

12 Zimmerman GA, Prescott SM, McIntyre TM. Endothelial cell interactions with granulocytes: tethering and signalling molecules. Immunol Today 1992;13:93-100.

13 Shimuzu Y, Newman W, Tanaka Y, Shaw S. Lymphocyte interactions with endothelial cells. Immunol Today 1992; 13:106-12.

14 Butcher EC. Leucocyte-endothelial cell recognition: Three (or more) steps to specificity and diversity. Cell 1991;67: 1033-6.

15 Springer $T$. Adhesion receptors of the immune system. Nature 1990;346:425-34.

16 Liu Y, Linsley PS. Costimulation of T-cell growth. Curr Opin Immunol 1992;4:265-70.

17 Müller GA, Markovic-Lipkovski J, Müller CA. Intercellular adhesion molecule-1 expression in human kidneys with glomerulonephritis. Clin Nephrol 1991;36:203-8.

18 Lhotta K, Neumayer HP, Joannidis M, Geissler D, Konig P. Renal expression of intercellular adhesion molecule-1 in different forms of glomerulonephritis. Clin Sci 1991; 81:477-81.

19 Seron D, Cameron JS, Haskard DO. Expression of VCAM-1 in the normal and diseased kidney. Nephrol Dial Transplant 1991;6:917-22.

20 Faull RJ, Russ GR. Tubular expression of intercellular adhesion molecule-1 during renal allograft rejection. Transplantation 1989;48:226-30.

21 Adu D, Luqmani R, Bacon P. Polyarteritis, Wegener's granulomatosis and Churg-Strauss syndrome. In: Maddison PJ, Isenberg DI, Woo P, Glass DN, eds. Oxford textbook of rheumatology. Vol 2. Oxford: Oxford Medical Publications, 1993:846-59.

22 Mason DY. Immunocytochemical labelling of monoclonal antibodies by the APAAP immunoalkaline phosphatase technique. In: Bullock GR, Petrusz P, eds. Techniques in immunocytochemistry. New York: Academic Press, 1985: 25- 42 .

23 Rees AJ, Cameron JS. Crescentic glomerulonephritis. In: Cameron S, Davison AM, Grünfeld J-P, Kerr D, Ritz E, eds. Oxford textbook of clinical nephrology. Vol 3. Oxford: Oxford Medical Publications, 1992:418-38.

24 D'Agati V, Chandler P, Nash ME, Mancilla-Jimenez RM Idiopathic microscopic polyarteritis nodosa: ultrastructural observations on the renal vasculature and glomerular lesions. Am f Kidney Dis 1986;7:95-110.

25 Weiss MA, Crissman JD. Renal biopsy findings in Wegener's granulomatosis: segmental necrotizing glomerulonephritis with glomerular thrombosis. Hum Pathol 1984;15:943-56.

26 Nakomota Y, Asano Y, Dohi K, Fujioka M, Iida H, Kida $\mathrm{H}$, et al. Primary IgA glomerulonephritis and SchönleinHenoch purpura nephritis: clinicopathological and imHenoch purpura nephritis: clinicopathological and im-
munohistological characteristics. $Q \mathcal{f}$ Med 1978;47:495516 .

27 Adu D, Howie AJ, Scott DGI, Bacon PA, McGonigle RJS Michael J. Polyarteritis and the kidney. $Q \mathcal{F}$ Med 1987;62 221-37.

28 Giangiacomo J, Tsai CC. Dermal and glomerular deposition of IgA in anaphylactoid purpura. Am $\mathcal{F}$ Dis Child 1977 131:981-3.

29 Noronha IL, Kruger C, Andrassy K, Ritz E, Waldherr R. In situ production of TNF, IL1, IL2R in ANCA-positive glomerulonephritis. Kidney Int 1993;43:682-92.

30 Brouwer E, Huitema MG, Mulder AHL, Heeringa P, Van Goo H, Cohen Tervaert JW, et al. Neutrophil activation in vitro and in vivo in Wegener's Int 1994;45:1120-31. 
31 Abbott F, Tam FWK, Ryan JJ, Rees AJ. Human mesangial cells secrete interleukin $1 \alpha$ but not interleukin $1 \beta$, interleukin receptor antagonist or tumour necrosis factor. $\mathrm{Ne}$ phrol Dial Transplant 1992;7:997-1001.

32 Lovett DH, Larsen A. Cell cycle-dependent interleukin-1 gene expression by cultured glomerular mesangial cells. $\mathscr{f}$ Clin Invest 1988;82:115-1-22.

33 Pober JS, Cotran RS. Cytokines and endothelial cell biology. Physiol Rev 1990;70:427-51.

34 Schleimer RP, Sterbinsky SA, Kaiser J, Bickel CA, Klunk $\mathrm{DA}$, Tomioka K, et al. IL-4 induces adherence of human eosinophils and basophils but not neutrophils to endoeosinophils and basophils but not neut

35 Thornhill MH, Haskard DO. IL-4 regulates endothelial cell activation by IL-1, tumour necrosis factor, or IFN $\gamma$. $\mathcal{J}$ Immunol 1990;145:865-72.

36 Bruijn JA, Dinklo NJCM. Distinct patterns of expression of intercellular adhesion molecule-1, vascular cell adhesion molecule-1, and endothelial-leukocyte adhesion molecule1 in renal disease. Lab Invest 1993;69:329-35.

37 Pall AA, Garner CM, Richards GM, Howie AJ, Adu D, Taylor CM, et al. Expression of E-selectin in the human kidney. Nephrol Dial Transplant 1993;8:1429-30.

38 Rubin-Kelley VE, Jevnikar AM. Antigen presentation by renal tubular epithelial cells. $\mathcal{f} \mathrm{Am}$ Soc Nephrol 1991;2: renal tu-26.

39 Kirby JA, Ikuta S, Clark K, Lennard TWJ, Taylor RMR. Renal allograft rejection: investigation of alloantigen presentation by cultured human renal epithelial cells. Im munology 1991;72:411-17.

40 Garner CM, Richards GM, Adu D, Pall AA, Taylor CM Richards NT, et al. ICAM-1 and VCAM-1 expression and function on cultured human glomerular epithelial cells. Clin Exp Immunol 1994;95:322-6.

41 Marsden PA, Cybulsky MI, Brenner BM, Brady HR. Regulated expression of vascular cell adhesion molecule (VCAM-1) in human glomerular mesangial cells (MC) [abstract]. ₹ Am Soc Nephrol 1991;2:553.

42 Jimenez W, Takata S, Matsubara M, Goldberg M, Lamas S, Brenner BM, et al. Cytokine-induced endothelial and mesangial cell ICAM-1 and VCAM-1 expression: evidence for involvement of oxygen radicals in TNF signalling. $f$ Am Soc Nephrol 1992;3:496.

43 Lin Y, Kirby JA, Clark K, Shenton BK, Forsythe JL, Proud $\mathrm{G}$, et al. Renal allograft rejection; induction and function of adhesion molecules on cultured epithelial cells. Clin Exp Immunol 1992;90:111-16.

44 Lin Y, Kirby JA, Browell DA, Morley AR, Shenton BK, Proud G, et al. Renal allograft rejection: expression and function of VCAM-1 on tubular epithelial cells. Clin Exp Immunol 1993;92:145-51.

45 Ishikura H, Takahashi C, Kanagawa K, Hirata H, Imai K, Yoshiki T. Cytokine regulation of ICAM-1 expression on human renal tubular epithelial cells in vitro. Transplantation 1991;51:1272-5.

46 Kawasaki K, Yaoita E, Yamamoto $T$, Tamatani $T$, Miyasaka M, Kihara I. Antibodies against intercellular adhesion molecule-1 and lymphocyte function-associated antigen-1 prevent glomerular injury in rat 1993;150:1074-83.

47 Kirby JA, Lin Y, Browell DA. Renal allograft rejection: examination of adhesion blockade by antilymphocyte antibody drugs. Nephrol Dial Transplant 1993;8:544-50. 